\title{
Use of Abbreviations in Social Media Accounts of Public Officials and Their Impact on Communication Effectiveness
}

\author{
Frisca Dilla ${ }^{1}$ Agustina ${ }^{1, *}$ \\ ${ }^{1}$ Indonesian Education Departement, Universitas Negeri Padang, Padang, West Sumatra, Indonesia \\ ${ }^{*}$ Corresponding author. Email: agustina@fbs.unp.ac.id
}

\begin{abstract}
This research aims to describe the type of abbreviation and the process of forming abbreviations used by public officials in their personal social media accounts. This research is qualitative in nature because the data taken are in the form of words or sentences contained in the tweets of 10 national-level public officials on their respective twitter accounts. The data collection technique uses a note-taking technique, namely marking and recording tweets from the accounts of public officials using abbreviations to then be classified based on the five types of abbreviations, namely abbreviations, acronyms, contractions, fragments, and letter symbols. The results showed that the most widely used type of abbreviation in social media accounts of public officials was abbreviations, while the least used was contraction. Likewise, letter preservation is the most common abbreviation formation process due to its easy and simple formation process. Furthermore, it was also found that other forms of abbreviation were used, namely: (1) affixation of abbreviations; (2) reduplication of abbreviations; (3) combination of abbreviations; (4) elimination of abbreviations; and (5) abbreviation of shorts; and merging of abbreviations is the most dominant one found because the more merging of several abbreviations is done, the more space and time will be saved on social media.
\end{abstract}

Keywords: abbreviation, social media, public officials

\section{INTRODUCTION}

Words are one of the most important elements in language. The development of words in language has a relationship with the evolution and social behavior of humans, so that over time, tens or even hundreds of new words are created according to their function.

When someone does the communication process with the other person, he will think how to convey the right information in a short time with limited words. This is what encourages someone to have the idea to carry out a word shortening process so that the abbreviation process appears in some of the tweets he writes. The phenomenon of the use of abbreviations occurs at all levels of society, and public officials are noexception, especially on social media, such as twitter.

As a representative people, public officials use formal and semi-formal written language when conveying their tweets related to government conditions, state finances, and also the condition of the Covid-19 outbreak which is currently a common concern. In the use of formal and semi-formal written language, public officials often use a shortening process (abbreviation) with a certain meaning. The meaning in question can be the real meaning, or the meaning that is not true, or it can also be called a play. The factor that influences public officials to use formal or semi-formal abbreviations is so that the communication process takes place comfortably. So, the use of this variety of written language is appropriate to the situation, the topic of conversation, and the relationship between public officials and their followers on social media.

The process of shortening the word is included in the form of abbreviation. According to Kridalaksana, abreviation is the process of dating one or more lexemes which causes the formation of a new form with the status of a word. Based on the type, Kridalaksana divides abbreviations into five forms, namely abbreviations, fragments, acronyms, contractions, and letter symbols [1].

The process of shortening or abbreviations with various types in Indonesian arises because of the human condition that is forced to speak practically and quickly [1]. This need is most felt in the branches of science, scouting, generation, and then followed by everyday people. Likewise with the use of abbreviations on twitter. In twitter media, people usually use the abbreviationbecause twitter has its own boundaries that cannot be violated [2]. When someone wants to convey a message in large numbers, twitter can't accommodate it due to limited space. So from there came the solution to use abbreviations so that the message can be conveyed. However, the use of various types of shortening creates another impact in the community. When a new word is created, other people tend to imitate and then use it so that the new word is quickly recognized by all levels of 
society. In this case, a person's creativity in playing words develops very rapidly, along with the development of the use of the word it is very interesting to use. This phenomenon is also used by the government. That is, to show a relaxed attitude by not reducing his authority in front of the public, public officials also do not escape the use of short language through their tweets on twitter. For example, the use of the words tks, yang, dg, which are commonly used by social media users, is also used by public officials.

However, as representatives of the people, public officials must pay attention and consider whether or not the public understands the use of abbreviations in the information they convey. This is because the use of abbreviations can have a considerable influence on the reader [3]. The development of abbreviations that are too free can lead to the emergence of multiple interpretations. For example, the general public understanding form of "twee which is usually used for the word "tahue, or ,tau ${ }^{\mathrm{ee}}$, but in Susi Pudjiastuti's twitter account the use of the word is a shortened form of the word „twittere

Previous research on abbreviation was carried out by Ermanto [4] and [6] which discussed the forms of using oral and written abbreviations in Indonesian in general with the results that there were more shortenings in the written variety than in spoken language and the most common pattern found was the pattern of combining the initial phonemes of words. Then, the research conducted by Adnan [7] on abbreviations shows that there are several types of abbreviations in the Jawa Pos newspaper published on October 20, 2018, including abbreviations, acronyms, fragments, contractions, and letter symbols. Furthermore, research conducted by Cenderamata and Sofyan [5] found that The most common forms of abbreviations used on social media are acronyms and abbreviations for several reasons respondents, namely: to save time, fill space when communicating, and denotes a social group.

The abbreviation process is the most developed process. Therefore, related to the previous explanation, the purpose of this study is to examine the use of types, processes of formation, and other forms of abbreviations in social media accounts of public officials.

\section{METHOD}

This type of research is qualitative with descriptive methods, namely research procedures in the form of collecting, processing, reducing, analyzing, and presenting data objectively or in accordance with the reality in the field. This research is qualitative because the data taken are in the form of words or sentences sourced from tweets from public officials' accounts on twitter, totaling 10 public officials: (1) @Fahrihamzah; (2)@susipudjiastuti; (3) @ mohmahfudmd; (4) @tifsembiring; (5) @fadlizon; (6) @SBYudhoyono; (7) @ganjarpranowo; (8) @KhofifahIP; (9) @ ridwankamil; and (10)@sandiuno. The data taken are the tweets of these public officials during the months of JuneDecember 2020

The data collection technique used the method of observing with the note-taking technique. The steps taken are to observe the overall tweets of public officials, then mark the tweets containing abbreviations. Next, classify the data based on the five types of abbreviations, namely abbreviations, fragments, acronyms, contractions, and letter symbols, then enter the data into a data collection table format.

\section{FINDING AND DISCUSSION}

Based on The research that has been done, obtained the use of abbreviations in the social media accounts of public officials as much as 550 data, then studied based on the type and process of its formation and the impact of the effectiveness of its use.

\subsection{Use of Abbreviation Types}

Based on the results of data analysis, it was found that five types of abbreviations were used in the social media accounts of public officials, as shown in table 1 .

Table 1. Types of Abbreviations in Public Officials' Social Media Accounts

\begin{tabular}{|l|l|l|}
\hline $\begin{array}{l}\text { Abbreviation } \\
\text { Type }\end{array}$ & $\begin{array}{l}\text { Amount of } \\
\text { data }\end{array}$ & Percentage \\
\hline Abbreviation & 366 & $66.55 \%$ \\
\hline Acronym & 147 & $26.72 \%$ \\
\hline Contraction & 9 & $1.64 \%$ \\
\hline Fragment & 20 & $3.64 \%$ \\
\hline Letter Symbol & 8 & $1.45 \%$ \\
\hline Amount & 550 & $100 \%$ \\
\hline
\end{tabular}

Abbreviations are the most dominant type of abbreviation found, namely 270 data consisting of visual and auditive abbreviations, of which are contained in the following tweet.

(1)Mobil Lab PCR BSL3 dan armada puluhan mobil tes covid $\boldsymbol{s} \boldsymbol{d h}$ dikirim ke kota/kab Se Jabar utk melakukan SIDAK di tempat2 keramaian/ kerumunan $\boldsymbol{u t k}$ memastikan tidak ada persebaran covid selama AKB ini $\boldsymbol{j g}$ meningkatkan rasio testing covid sebanyak mungkin sesuai standar WHO. (RK$01: 1 / 6 / 20)$

In data (1), there are two types of abbreviations, namely auditive and visual. The visual abbreviations $s d h$, $u t k$, $l a b, k a b, j g$ are abbreviations that are not spelled letter by letter and are only in written form, but when spoken they 
are always in the form of extension, namely sudah, untuk, labor, kabupaten, and juga. Next are auditive abbreviations: $P C R, A K B$, and $W H O$, which are types of abbreviations that are spelled letter by letter, both in written and spoken language, such as $P C R$ from Polymerase Chain Reaction, AKB from Adaptasi Kebiasaan Baru, and WHO from World Health Organization. In addition, data (1) also found acronyms jabar and SIDAK from Jawa Barat compound words and inspeksi mendadak.

\section{Acronym}

Based on the results of data classification, it was found that 147 acronyms were used, including a tweet from a public official as follows.

(2)Kita memang mendengar Pemerintah akan memberikan $B L T$ (Bantuan Langsung Tunai) bagi 2,4 juta petani miskin sebesar Rp600 ribu. Itupun, uang tunai $y g$ akan diterima oleh petani hanya Rp300 ribu, karena sisanya akan diberikan dalam bentuk Saprotan. (FZ03:8/6/20).

On data (2), it was found that the abbreviations of the acronym types were jabar, SIDAK, and Saprotan. Jabar is an acronym for Jawa Barat, SIDAK for inspeksi mendadak, and Saprotan for Sarana Produksi Pertanian. In the form of Saprotan, the word sarana is taken from the first syllable of the first word, namely sa, produksi from the first syllable of the second word is pro, and pertanian from three letters in the middle of the third word, namely tan. This acronym process does not follow the existing customary rules because the third word takes three middle letters so that the shortening results are also less pleasant to hear. In addition to acronyms in data (1), the abbreviation BLT is Bantuan Langsung Tunai and $y g$ from yang, also symbolizing the letter $R p$ from rupiah.

In this study, 9 types of contraction abbreviation were found, including the following.

(3)Kalian boleh secara terus menerus menggunakan lobby dan kekuasaan untuk mengukuhkan kuasa dunia. Tapi, kebenaran takkan pernah dilumpuhkan. Ia akan selalu mencari jalannya. Keinginan membangun tradisi partai politik yang baik tidak bisa dikalahkan. Takkan pernah! (FH224:28/11/20)

Based on data (3), the type of contraction abbreviation takkan comes from tidak akan, which undergoes the process of shrinking some phonemes. In word tak, there is contraction of phonemes

/i/ and /d/ so that they become tidak, while in words akan, there is a contraction of the phonemes /a/ so that they become akan. These two words when combined form a new word that is takkan. This form of contraction is acceptable and can be pronounced as a natural word.
There are 20 types of fragment abbreviation found, some of which are as shown in the following example.

(4)Pokoknya, jangan kasih kendor sampai semua Kabupaten/Kota berstatus hijau dan covid berhenti menyebar. Tetap jaga $3 M$ ya lur. (KIP/158/27/10/20)

(5)Ijin tum, kemarin di Jogja. Sekarang lagi di jambi. (FH-162:1/11/20)

On data (4) and (5), found the type of abbreviation of lur and tum. The word lur is a fragment of the word Sedulur (from Javanese), while tum is a fragment of ketum which is also an acronym for the general chairman of FH. Data (4) also found the abbreviation of the acronym covid from the word corona diserse and the abbreviation $3 M$ from the word 3 Milyar.

The type of letter symbol abbreviation in this study found a total of 8 data. An example of the data is as follows.

(6)Panjang tali kapal cantrang yg segede lengan orang dewasa rata rata $6 \mathbf{k m}$; beratnya pasti ton-tonan .. daya sweeping yg $2 \mathbf{~} \mathbf{~ m}$ saja 280 ha .. yg $6 \mathbf{k m}$ bisa dibayangkan dasar laut akan rusak.

(SP-35:24/7/20)

Based on data (6), the type of abbreviation of the letter symbol $\mathrm{km}$ is from the word kilometer, while ha from the word hektar. Both forms include a classification of letter symbols that mark the size and type of visual abbreviation, namely $\mathrm{km}$ is pronounced kilometer and ha is pronounced hektar. In addition to letter symbols, in data (6) there is also a visual abbreviation, namely $y g$ from yang.

\subsection{Abbreviation Formation Process}

Based on its formation, this study found three abbreviation processes in the accounts of public officials as shown in table 2 .

Table 2. The Process of Formation of Abbreviations in Social Media Accounts of Public Officials

\begin{tabular}{|l|l|l|}
\hline $\begin{array}{l}\text { Abbreviation Formation } \\
\text { Process }\end{array}$ & $\begin{array}{l}\text { Lots of } \\
\text { Data }\end{array}$ & Percentage \\
\hline $\begin{array}{l}\text { Font Reduction } \\
\text { Process }\end{array}$ & 437 & $79.74 \%$ \\
\hline Syllable Retention Process & 36 & $6.57 \%$ \\
\hline $\begin{array}{l}\text { Letter and Syllable } \\
\text { Retention Process }\end{array}$ & 75 & $13.69 \%$ \\
\hline Amount & 548 & $100 \%$ \\
\hline
\end{tabular}

Letter Preservation

Based on the data findings, the formation of abbreviations with the letter preservation process is the most commonly found, which is a total of 437 data(79.74\%). The formation process is as follows. 
(1)Praxis demokrasi kerap berkendala. Ide baik sering sulit diwujudkan $\boldsymbol{k r n}$ tergantung $\boldsymbol{j g} \boldsymbol{p d}$ institusi dan pejabat lain $y g$ wewenangnya $j g$ dijamin oleh UU. $T p$ demokrasi tetap $l b h$ baik daripada monarki $k r n$ demokrasi tak scr mutlak menggantungkan diri $\boldsymbol{p d}$ kekuasaan "seorang" monark. (MD-45:3/9/20)

In data (7), there are four types of abbreviations with the process of preserving the first letter of each syllable, namely krn from karena, jg from juga, pd from pada, and scr from secara. The four abbreviations have the same pattern of abbreviation formation because they consist of three syllables, namely $k a$, $r e$, and $n a$, then the first letter of each syllable is taken, namely $k, r$, and $n$. Likewise with the other abbreviations $j$ and $g, p$ and $d$, and $s, c$, and $r$.

Abbreviation formation process with syllable preservation process found a total of 36 data with the formation process as follows.

(2)Jendral (Purn) Try Sutrisno: "Ideologi Bangsa Ter-cabik2, Purnawirawan TNI Polri Desak RUU HIP Dicabut". Itu jg sikap FKPPI, MUI, Muhammadiyah, NU, Aliansi Perempuan Peduli Indonesia $d l l$. Itu juga $y g$ saya sampaikan dlm Rapim MPR. Smoga $D P R \quad$ dapat melaksanakanya. (HNW/17/23/6/20)

Based on data (8), the type of abbreviation rapim, which is an acronym for rapat pimpinan. This acronym undergoes a process of perpetuating the first syllable of each component, namely the first component $r a$ and the second component is taken from the first syllable of the second word, namely pim. The two syllables are manifested as an acronym form of the compound word rapat pimpinan. The aim is to streamline understanding and streamline the time and place of writing. In contrast, the acronym Purn uses the process of preserving the first four letters of each component; the acronym Polri is formed from the process of perpetuating the first three letters of the first component and the first letter of the next component; MUI and HIP are formed by perpetuating the first letter of each component. Data (8) also found the abbreviation $R U U$ from Rancangan Undang-Undang and the FKPPI from Forum Komunikasi Putra-Putri Purnawirawan Indonesia.

The formation of abbreviations with the letter preservation process found a total of 75 data. The process of forming abbreviations by preserving letters and syllables found is the preservation of letters and syllables which are difficult to formulate. The process of forming the abbreviation will be explained in detail as follows.

(3)Patimban Port dekat tol Cipali \& dilewati jalur kereta api. Ia adalah bag terpenting selain Bandara Kertajati divisi kawasan ekonomi

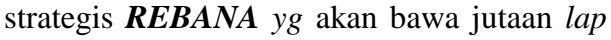
kerja. Insya Allah Pelabuhan Patimban jd simbol kebangkitan \& kejayaan ekonomi Jabar \& Indonesia. Aamiin. (RK-40/13/8/20). Based on data (9), there is a form of REBANA which is a type of acronym abbreviation with the process of perpetuating various letters and syllables that are difficult to formulate. REBANA consists of three components, namely Cirebon, Patimban, Majalengka. The first component of Cirebon undergoes the process of perpetuating the second syllable, namely re; the second component of Patimban undergoes the process of perpetuating the sixth and seventh letters, namely $b a$; while the third component of Majalengka undergoes the process of preserving the last letter, namely $a$, so that it is combined into REBANA as the embodiment of Cirebon, Patimban, Majalengka. However, the process of forming this acronym is less common and less acceptable in terms of mentioning or being heard so that understanding is less effective. In data (9) also found the acronym Cipali and fragments of lap and $j d$. The process of forming Cipali includes the addition of the first two letters of $\mathrm{Ci}$ in the first component of Cikopo and the first four letters of Pali in the second component of Palimanan to form the acronym Cipali. Furthermore, lap is included in the perpetuation of the first three letters of the word lapangan; while $j d$ is included in the preservation of the first letter of each finished syllable, namely jadi.

\subsection{Other Forms of Abbreviation}

In this study, other forms of abbreviation were found in the accounts of public officials in five forms, as in table 3

Table 3. Other Forms of Abbreviation in Social Media Accounts of Public Officials

\begin{tabular}{c|l|c|c|}
\hline Nu. & $\begin{array}{l}\text { Other Forms of } \\
\text { Abbreviation }\end{array}$ & $\begin{array}{c}\text { Amount } \\
\text { of data }\end{array}$ & $\begin{array}{c}\text { Percen } \\
\text { tage }\end{array}$ \\
\hline 1. & $\begin{array}{l}\text { Affixation of } \\
\text { abbreviations }\end{array}$ & 3 & $3.70 \%$ \\
\hline 2. & $\begin{array}{l}\text { Reduplication of } \\
\text { Short }\end{array}$ & 2 & $2.47 \%$ \\
\hline 3. & $\begin{array}{l}\text { Combination of } \\
\text { abbreviations }\end{array}$ & 59 & $72.84 \%$ \\
\hline 4. & $\begin{array}{l}\text { Elimination of } \\
\text { abbreviations }\end{array}$ & 15 & $18.52 \%$ \\
\hline 5. & Abbreviations of shorts & 2 & $2,47 \%$ \\
\hline & Amount & 81 & $100 \%$ \\
\hline
\end{tabular}

Based on the results of data analysis, affixation of abbreviations was found as many as 3 data, including the following.

(7)Kalau ybs senang bersosmed maka tidak ada istilah tidak dikenal. Riwayat $y b s$ terlalu terang. Tidak bisa sembunyikan. Ini kesempatan yg baik bagi pihak kemanan kita untuk membuka secara terang. Ayo 
@DivHumas_Polri kamu bisa! Bismillah! (FH-71:14/9/20)

Data (10) bersosmed is an acronym type abbreviation that has affixation to abbreviations. Bersosmed is an acronym for media sosial, which is affixed with prefixes ber- on the acronym sosmed which changes its grammatical meaning and morphological process into lexicalization bersosmed which is another form of bersosial media abbreviation.

Reduplication of the abbreviation was found as many as 2 data, including the following.

(8)According to the Minister of State-Owned Enterprises to me, an MoU with Muhammadiyah and MUI will also be explored soon so that these mass organizations can send lecturers in mosques and ta'lim councils in the neighborhood $B U M N$. MoU just done with NU, others will follow later

(MD-211:22/11/20)

In data (11), the acronym of ormas- ormas undergoes reduplication in the form of an abbreviation of organisasi massa- organisasi massa. The acronym for ormas undergoes a repetition process so that it becomes ormasormas.

Combination of abbreviations is another form of abbreviation that is most dominantly found, which is 59 $(72.84 \%)$. The data include the following.

(9)Sebagai Ketua BKSAP DPR RI, sy menerima audiensi dari Ketua International Association for Public

Participation (IAP2), P Aldi Alizar, Ibu Sheila Tetra Carina (Wakil Ketua IAP2) dan Andry Sose (Delivery and Engagement Manager IAP2 Indonesia) di Fadli Zon Library. (FZ-02:8/6/20)

Data (12) BKSAP DPR RI is an abbreviation of the type of abbreviation with the combined form of abbreviations. The three components are included in the process of combining abbreviations + abbreviations + abbreviations. BKSAP DPR RI is an abbreviation of Badan Kerja Sama AntarParlemen Dewan Perwakilan Rakyat Republik Indonesia. The form of the abbreviation BKSAP DPR RI consists of combining three abbreviations, namely $B K S A P+D P R+R I$. The combined abbreviations are included in other forms of combination of abbreviations. The process of eliminating the abbreviations found a total of 15 data, including the following.

(10) Robot $\boldsymbol{K E C E}$ ini memiliki kemampuan khusus untuk membantu kerja para tenaga medis. Mulai dari mengantar makanan, alat medis hingga menjadi alat sterilisasi ruangan.

(KIP-29:13/7/20)

In data (13), it is found that the type of abbreviation for the acronym $K E C E$ is found with the process of eliminating the abbreviation. $K E C E$ is an acronym from Kreatif, Energik, Cantik, and Elegan. KECE consists of five components, namely Kreatif, Energik, Cantik, dan, Elegan. This acronym undergoes a process of removing the conjunction and. So, each of these components is taken the first letter, namely $k, e, c, e$ into a unified form of the acronym KECE. This form of acronym was created by the Governor of East Java, Khofifah Indar Parawansa, to name robots with special abilities that function to help the work of medical personnel.

The abbreviation process for the abbreviation of shorts was found as many as 2 data, including the following. Bisa dimengerti. Dan "hanupis" unt kesetiaannya pilih $P K \& P K S$. Tapi sudah saya sampaikan $j g$, dari dulu lambang warna $P K S$ adalah PUTIH. Kalaupun skrg $P K S$ hadirkn oranye (warna yg juga dipakai olh BNPB\& Basarnas), itu unt penyegaran. Tapi lambang warna $P K S$ tak berubah, TETAPPUTIH. Salam. (HNW/232/29/11/20)

Data (14) Basarnas is a type of acronym abbreviation by experiencing abbreviations of shorts. Basarnas is an acronym from Badan SAR Nasional, in which there is also an acronym $S A R$, namely Search and Rescue.

\subsection{The Impact of Using Abbreviations on Communication Effectiveness}

Based on the data findings, the most dominant type of abbreviation used is the abbreviation typewith a shortening process in the form of letters or a combination of letters spelled out letter by letter. This indicates that public officials in their social media accounts choose to use the type of abbreviation abbreviation, which is an abbreviation that is more practical to use and saves space considering that social media twitter is a place to convey information that has limited space. Especially in today's era, everything is practical and requires everyone to do everything quickly. The findings of this study are in line with research conducted by Zikra (2016); Mardani (2017); Verlin

(208); Adnan (2019); and Cenderamata \& Sofyan (2019) showed that the most dominant abbreviation used was the abbreviation type.

The use of abbreviations in this study proves that public officials are creative in language. This can be seen from the existence of new forms of abbreviation, including the abbreviation KECE from Kreatif, Energik, Cantik, and Elegan, PTASA from Perlindungan Tokoh Agama dan Simbol Agama; BDR from Belajar dari Rumah. Then, there are also new acronyms, including Kulwit from Kuliah Twitter, gercep is an acronym of gerakan cepat, Bodebek from Bogor Depok Bekasi,

Tapera from tambahan penderitaan rakyat, and DAS from Daerah Aliran Sungai. Creative language can also be seen from the formation of new patterns of the abbreviation process, including through the disappearance of some words, such as manteman from 
teman-teman; elimination of abbreviations, such as napiter acronyms from narapidana kasus terorise, and abbreviations of shorts, such as $M D 3$, the acronym for $M P R, D P R, D P R D, D P D$; and so on. These new findings as another form of abbreviation have an impact on making communication more effective, because it can shorten the writing time and is also easily understood by the readers.

However, in this study also found the process of forming abbreviations with irregular letters perpetuation, such as smp for the word sampai, intl for the word internasional, simpulkn for the word simpulkan, and skg for word sekarang. Likewise, the use of abbreviations with the preservation of letters and syllables that are difficult to formulate, among others PNPS from penetapan presiden, PEPES from Perhimpunan Penggerak Indonesia Sejahtera, REBANA from Cirebon Patimban Majalengka, and Saprotan from Sarana Produksi Pertanian.

The use of irregular abbreviations results in ineffective communication because it will be confusing to understand it, giving rise to various reactions from netizens as the reading community. This can be seen from the incomprehension of netizens by expressing their comments. Here are some comments as netizen reactions to the irregular acronym:

(1) REBANA singkatan dari apa ya? (dari tadi mencoba mencocok-cocokan wilayah yang terhubung, kok belum пети) (Q:3/12/20);

(2) saprotan iki opo? (Dk:20/6/20);

(3) yang anak pertanian kasih tahu dong apa itu saprotan? $Q$ bingung (LS:20/6/20); dan

(4) Saprotan itu apa sih? Ngetweet aja gajelas gini (DT:20/6/20)

\section{CONCLUSION}

Based on these findings, it can be concluded that the type of abbreviation abbreviation is the most common type of abbreviation found in the social media accounts of public officials. This is due to its simple formation and does not require much space and does not require much time to write it down. Then, the most common abbreviation formation process is the letter preservation process. This is because not only is the process of formation easy and simple for the author or creator, but also easy and simple to associate and understand by the readers.

With the many findings on the use of abbreviations in social media accounts of public officials, it proves that: (1) public officials are very creative, as evidenced by the forms of abbreviations that include abbreviations, fragments, acronyms, and contractions used; (2) the patterns of the abbreviation formation process in the social media accounts of public officials have also developed with the existence of new formation patterns in the abbreviation formation process which so far have not found the patterns of the abbreviation formation; (3) other forms of abbreviation in the social media accounts of public officials that are found to be more concise in the use of abbreviations when communicating, because in abbreviations there are also several forms such as affixes, reduplications, deletions, mergers, and abbreviations of abbreviations;

However, in this public official's account, it was also found that the use or creation of acronyms was less common because it was difficult for netizens to understand and associate them as readers, so that they not only became foreign and funny to listen to but also resulted in ineffective understanding. Therefore, it is recommended to public officials or anyone who writes on social media to always comply with the rules of the formation of the abbreviation process with each characteristic of each while considering the beauty of the sound to be heard so that it is efficiently associated and effectively understood.

\section{ACKNOWLEDGMENT}

This article is the Results of the collaborative research of the Master Thesis Research Scheme 2021. Therefore, the authors express their thanks to the Chancellor of UNP and the Head of LP2M for the implementation of this reseach.

\section{REFERENCES}

[1] H. Kridalaksana, Pembentukan Kata dalam Bahasa Indonesia, Jakarta: PT Gramedia Pustaka Utama, 1992.

[2] S. N. Ardini, "Analysis of acronym anabbreviations in IJAL Journal", Journal of English Language Learning (JELL, vol. 3, pp. 9-21, 2019.

[3] L. Bauer, Introducing Linguistic Morphology, Great Britain: Edinburgh University Press, 2003.

[4] Ermanto, "Pemendekan (abreviasi) dalam bahasa Indonesia: suatu tinjauan struktural", J. Humanus, vol. 2000. 2, DOI: https://doi.org/10.31227/osf.io/2f3rs

[5] R. C. Cenderamata, A. N. Sofyan, "Abreviasi dalam percakapan sehari- hari di media sosial: suatu kajian morfologi (abbreviation in everyday conversation on social media": a morphological study), Prasasti: Journal of Linguistics, vol. 4, pp. 69-77, 2020. DOI: https://doi.org/10.20961/prasasti.v4i 1.24166 
[6] G. Keraf, Tata Bahasa Indonesia, Jakarta: Nusantara, 1997.

[7] M. S. Adnan, “Abreviasi pada berita dalam Surat Kabar Jawa Pos”, J. Belajar Bahasa: Jurnal Ilmiah Program Studi Pendidikan Bahasa dan Sastra Indonesia, vol. 4, pp. 201- 206, Oct. 2019. 